\title{
Volcanic Stratigraphy and Potential Hazards of the Chihsingshan Volcano Subgroup in the Tatun Volcano Group, Northern Taiwan
}

\author{
Yu-Wei Tsai ${ }^{1,3}$, Sheng-Rong Song ${ }^{2, *}$, Huei-Fen Chen ${ }^{4}$, Shu-Fen $\mathrm{Li}^{5}$, Ching-Hua Lo ${ }^{2}$, \\ Wei $\mathrm{Lo}^{3}$, and Shuhjong Tsao ${ }^{6}$ \\ ${ }^{1}$ Department of Geology, Chinese Culture University, Taipei, Taiwan, ROC \\ ${ }^{2}$ Institute of Geosciences, National Taiwan University, Taipei, Taiwan, ROC \\ ${ }^{3}$ Institute of Mineral Resources Engineering, National Taipei University of Technology, Taipei, Taiwan, ROC \\ ${ }^{4}$ Institute of Applied Geosciences, National Taiwan Ocean University, Keelung, Taiwan, ROC \\ ${ }^{5}$ Taipei Municipal Renai Junior High School, Taipei, Taiwan, ROC \\ ${ }^{6}$ Central Geological Survey, Ministry of Economic Affairs, Taipei, Taiwan, ROC
}

Received 14 October 2008, accepted 22 February 2010

\begin{abstract}
The Chihsingshan Volcano Subgroup (CVSG) is one of the most important landforms located within the Tatun Volcano Group in northern Taiwan. Based on a Digital Terrain Model, contour maps and field investigations, the CVSG can be divided into four types of volcanic landforms: (1) a strato- or composite volcano, Chihsingshan; (2) domes, the Shamaoshan and a hidden unit; (3) lava cones, the Baiyunshan and the Hsiaotsaoshan; and (4) a scoria cone, the Chikushan. Meanwhile, many small craters are distributed linearly along two northeast trending normal-fault systems. The occurrences are predominantly lava flows with subsidiary fall deposits, pyroclastic flows, and lahars in which at least twenty layers of lava flow in the CVSG can be recognized. Among them, 16 layers in the Chihsingshan volcano, named as C1 - C16, two in the Baiyunshan, B1 - B2, and two in the Hsiaotsaoshan, H1 - H2. Our study suggests that the potential volcanic hazards include lava and pyroclastic flows and simultaneous or subsequent lahars, if the Chihsingshan erupts in a similar manner as in the past. A volcanic hazard zonation map can be constructed for the purpose of mitigation assuming the future eruptive center and eruptive volume.
\end{abstract}

Key words: Tatun Volcano Group, Chihsingshan Volcano Subgroup, DTM, Lava flow, Volcanic hazards

Citation: Tsai, Y. W., S. R. Song, H. F. Chen, S. F. Li, C. H. Lo, W. Lo, and S. Tsao, 2010: Volcanic stratigraphy and potential hazards of the Chihsingshan Volcano Subgroup in the Tatun Volcano Group, northern Taiwan. Terr. Atmos. Ocean. Sci., 21, 587-598, doi: 10.3319/TAO.2010.02.22.03(TH)

\section{INTRODUCTION}

The Tatun Volcano Group (TVG) is situated in northern Taiwan, at the north boundary of the Taipei Basin, and is located between the Chinshan and Kanchiao faults (Fig. 1). It is composed of at least twenty volcanic composites, cones and domes, which can be divided into five subgroups: Chutzeshan, Tatunshan, Chihsingshan, Huangtsuishan, and Nanshihshan-Tinghuohsiushan Volcano Subgroups (Chen and Wu 1971; Song et al. 2000a).

Many studies on the geology, petrology, geochemistry, geochronology and tectonic aspects of the TVG have been conducted in recent decades (Chen and $\mathrm{Wu}$ 1971; Chen 1975, 1978, 1983, 1990; Yen et al. 1984; Juang and Chen

\footnotetext{
* Corresponding author

E-mail:srsong@ntu.edu.tw
}

1989; Wang and Chen 1990; Juang 1993; Tsao 1994; Lee 1996; Teng 1996; Wang et al. 1999; Song et al. 2000a; Chen et al. 2003; Huang 2005). These studies have suggested that the volcanism began in $2.8 \sim 2.5 \mathrm{Ma}$, then ceased about one million years, resurged in $1.5 \mathrm{Ma}$ and lasted until $0.2 \mathrm{Ma}$. Thus, the TVG has usually been identified as a group of extinct volcanoes due to the absence of historically documented eruptions. However, recent data on tephras collected from the sediments of Taipei Basin suggests that the volcanic activity could have lasted until 1.8 ka or younger (Chen and Lin 2007). Meanwhile, signals related to volcanic activities, i.e., volcanic earthquakes, gas fumaroles, high geothermal flow and hot springs, have obvious activity currently, suggesting that the TVG might be classified as active according to Szakacs' definition (Szakacs 1994; Song et al. 2000b; Lin et al. 2005). It is important to monitor the magma 
activity of TVG due to the proximity of metropolitan Taipei, with over seven million inhabitants, and two nearby nuclear power plants. The Central Geological Survey (Ministry of Economic Affairs) thus initiated a large-scale four-year research program to re-survey the basic volcanology and reevaluate the potential for volcanic activity.

This study emphasizes the landforms, occurrence and lithofacies of volcanic deposits, then establishes the stratigraphy and geological map of the Chihsingshan Volcano Subgroup (CVSG). We hope the present study will provide basic data for evaluating volcanic activity and potential hazards with regards to any future eruptions.

\section{TECTONIC SETTING AND GEOLOGICAL BACKGROUND}

Quaternary volcanism in northern Taiwan consists of the Tatun, Chilung and Kuanyinshan Volcano Groups, and the offshore volcanic islets, i.e., the Chilungtao, Huapinghsu, Meinhuahsu and Pengchiahsu (Fig. 1). They are predominantly composed of andesites with few basalts and dacites (Chen 1978; Juang and Chen 1989). Tectonically, they are spatially associated with the Ryukyu Island Arc (Chen 1975; Yen 1978), where the Philippine Sea plate is northwardly subducting into the Eurasian plate (Wu 1978; Tsai et al. 1981; Suppe 1984). Although the related orogenic movement has occurred since $10 \mathrm{Ma}$, the volcanism in northern Taiwan may be due to the WNW movement and westerly encroachment of the subducting Philippine Sea plate in the collisional orogeny (Teng et al. 1992; Teng 1996). However, Wang et al. (1999) suggested that the magmatism in northern Taiwan might be related to the post-collisional collapse rather than arc volcanism.

The TVG is the most voluminous volcano in northern Taiwan; the group is composed of typical multivent volcanoes containing at least twenty volcanic composites, cones and domes in an area of $400 \mathrm{~km}^{2}$ (Chen and Wu 1971; Wang and Chen 1990; Song et al. 2000a). The spatial distribution of TVG is constrained along the flanks of Chinshan Fault except the Nantzeshan, Tinghouhsiushan and Patotzeshan volcanoes. They intersect at the Tatunshan Volcano forming a half amphitheater with a mouth opening to the northnortheast. The characteristics of amphitheater morphology in TVG indicate that it may have been formed by eruptions after a cauldron formation during the change in the regional stress field from compression to extension (Song et al. 2000a).

The volcanic rocks of TVG overlie a late Tertiary sedimentary basement and occur as lava flows, pyroclastic breccias, tuffs, lahars and reworked volcaniclastics. Lava flows with minor pyroclastic flows and fallout tuffs suggest that the TVG represents effusive or silent rather than an explosive eruption based on its low explosive index [tephra/ (tephra+lava)](Song et al. 2000a). Post volcanic activity, i.e., hot springs and gas fumaroles in the TVG are well developed and mainly distributed in the peripheries of main volcanic composites and cones along the Chinshan fault (Chen and $\mathrm{Wu}$ 1971).

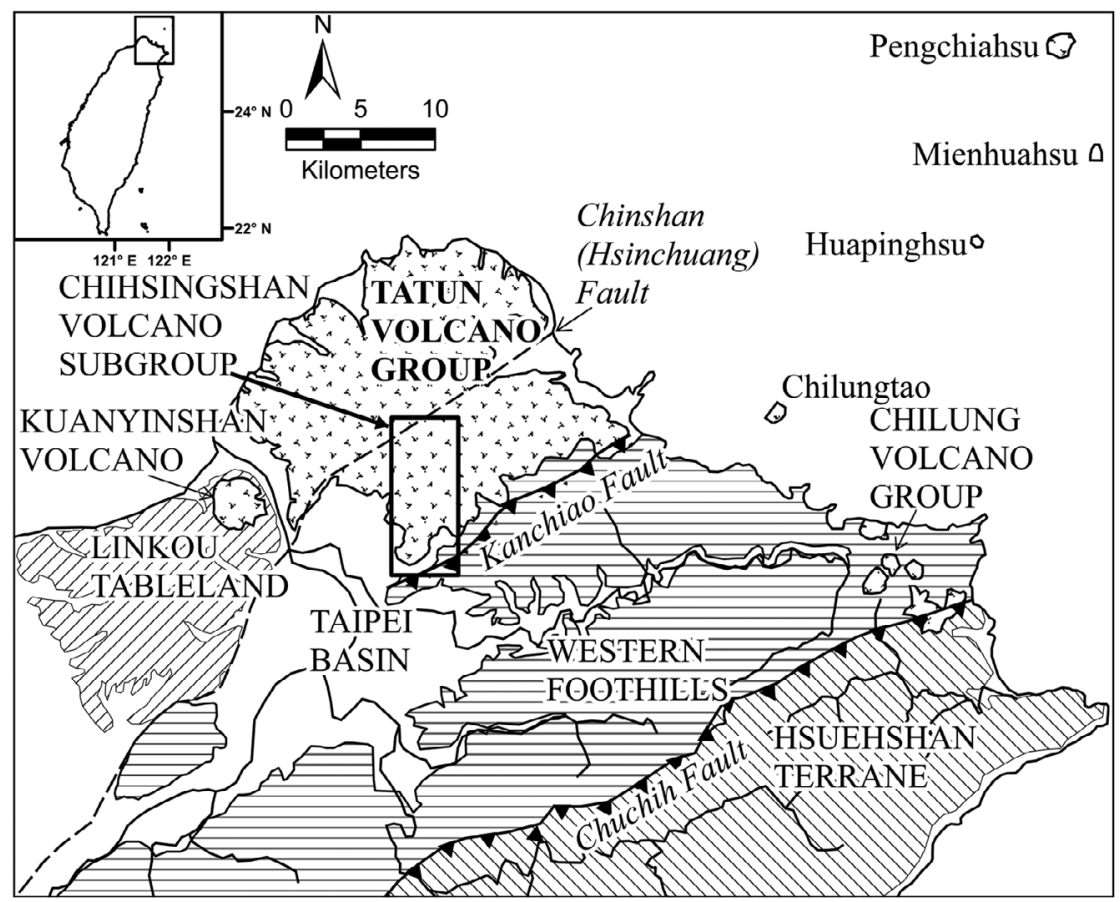

Fig. 1. Simplified map showing the geology and volcano distributions in north Taiwan and the study area, the Tatun Volcano Group and the Chihsingshan Volcano Subgroup (modified from Ho 1986; Chen 1990). 


\section{DIGITAL TERRAIN MODEL (DTM) AND VOL- CANIC LANDFORMS}

Digital Terrain Maps (DTM) usually utilize aerial/surface surveys to obtain topographic data and can be presented in three major ways: digital contour, triangulated irregular network (TIN) and regular grid (Miller and Leflamme 1958). In this study, we used traditional air-photo DTM with $10 \mathrm{~m} \times 10 \mathrm{~m}$ resolution as a general survey of topographic characteristics and LiDAR DTM with $2 \mathrm{~m} \times 2 \mathrm{~m}$ resolution to recognize fine structures in volcanic landforms and relationships of overlapping lava flows.

\section{RESULTS AND DISCUSSION}

\subsection{Volcanic Landforms}

Based on the DTMs, contour maps and field surveys, four types of volcanic landforms can be recognized in the CVSG: composite, cone, dome and crater (Fig. 2). The Chihsingshan volcano is a typical composite with an elevation of about $1120 \mathrm{~m}$ and is the highest peak in the TVG. It consists predominantly of lava flows with inter-layered pyroclastic flows and subsidiary fall tuffs to form a conically shaped volcano. Occurrences of huge amounts of discrete blocks with size ranging from few to tens of meters in diameter can be observed in the west, southwest and southeast parts of this volcano, which covers an area more than $6 \mathrm{~km}^{2}$ (Fig. 2). They show hummocky landforms with zigzag blocks which are the typical deposits of debris avalanche and originated by volcanic edifice collapse during volcanic activity or rockslides in non-eruptive periods (Siebert 1984). Two NE-SW treading structures, which may be normal faults having several small craters with diameters ranging from tens to hundred meters, cut through near the summit of the Chihsingshan. These observed characteristics suggest that Chihsingshan was unstable during the volcanic eruptions or non-erupted periods.

A volcanic cone is built by ejected fragment or effused lava from a vent, pilling up around the vent in the shape of a cone with or without a central crater (Ollier 1988). In the CVSG, Chihkushan is the only pyroclastic cone characterized by scoria deposits and is about $500 \mathrm{~m}$ in diameter at its base (Fig. 2). Two identified lava cones, Baiyunshan and Hsiaotsaoshan, are located to the southeast of CVSG at 429 and $590 \mathrm{~m}$ in altitude, and are about 200 and $350 \mathrm{~m}$ in diameter, respectively.

A lava dome, a roughly circular mound in shape is produced by viscous magma slowly protrudes up to the surface to form a volcano (Ollier 1988). Two lava domes can be identified in the CVSG (Fig. 2). One is located in the Shamaoshan, while the other is a hidden one located between mountains Chihsingshan and Chihkushan. The former is bell shaped and composed of lavas with a contracted depression at the summit $(643 \mathrm{~m})$. Accordingly, the latter is mound shaped, having an elevation a few meters higher than the surrounding area and is around $30 \mathrm{~m}$ in diameter. Chihkushan is difficult to identify in old aerial photographs, topographic maps and field surveys due to vegetation cover. It can be observed using LiDAR-DTM which can virtually remove surface vegetation and buildings (Fig. 2).

Two linear distributions of volcanic craters, which are circular to elliptic depressions caused by volcanic explosions, can be recognized in the east and at the summit of Chihsingshan volcano (Fig. 2). They are distributed along two surface normal-fault traces and their diameters range from few to tens of meters. Generally, the craters occur on vents where magma erupts as gases, lava and ejecta (Ollier 1988). Distributions of those craters, thus, infer that the magmas or gases rose from along the fractures or cracks of fault planes and exploded to the surface to form the landform. Meanwhile, they are preserved well which suggests that the last eruption may have occurred recently in the CSVG.

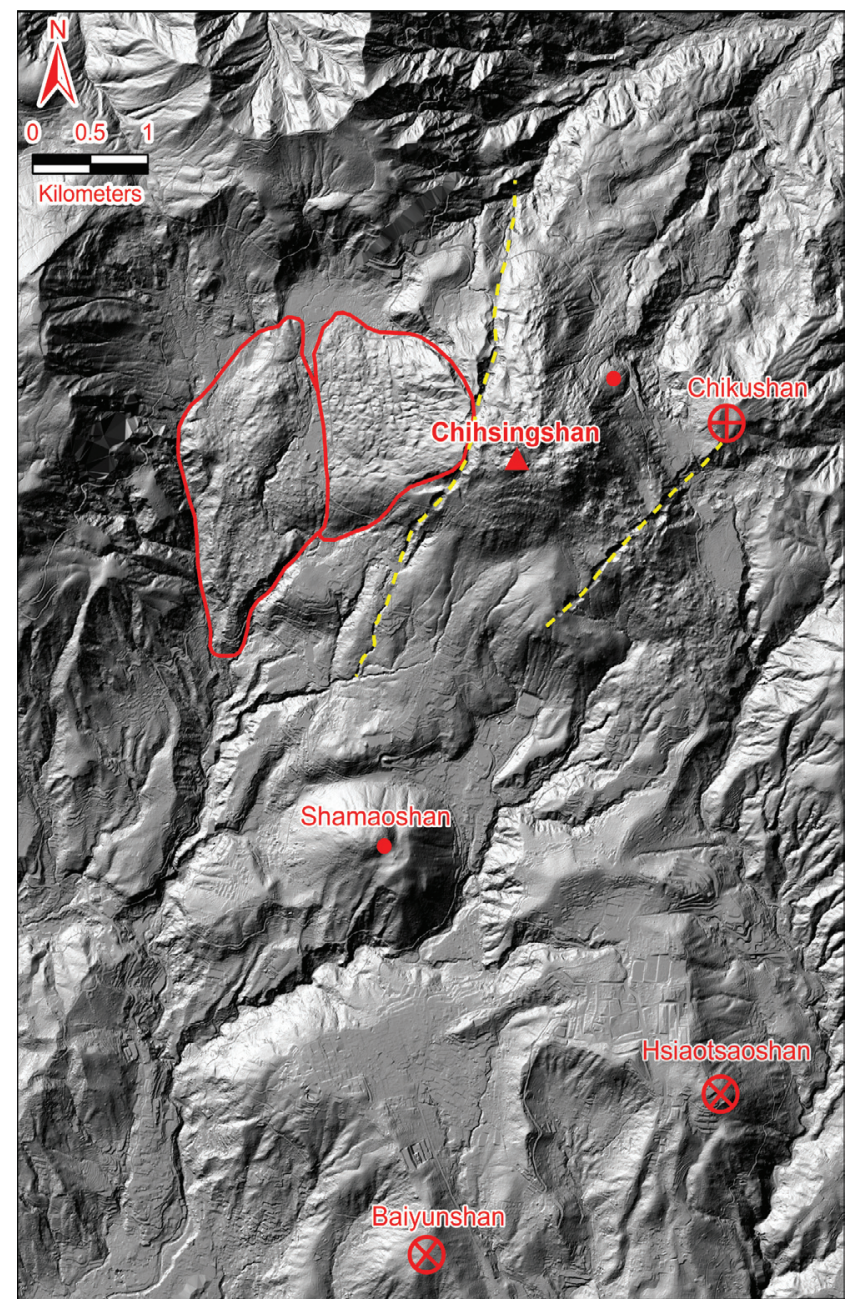

Fig. $2.2 \mathrm{~m} \times 2 \mathrm{~m}$ LiDAR DTM showing the distributions of volcanic landforms in the Chihsingshan Volcano Subgroup. $\mathbf{\Delta}$ : composite volcano; $\bullet$ lava dome; $\oplus$ : scoria cone; $\otimes$ : lava cone. Yellow dashed line: Trace of normal fault with linear distributions of crater. 


\subsection{Volcanic Deposits}

The volcanic deposits in the CVSG can be classified into four lithofacies, namely, lava flows, pyroclastic breccias, tuffs, and volcaniclastic deposits including lahar and fluvial products (Fig. 3). Pyroclastics and volcaniclastics represent the primary deposits of eruption and partial and/or re-deposited volcanic detritus, respectively.

\subsubsection{Lava Flows}

The CVSG is predominantly composed of lava flows with minor pyroclastics and volcaniclastics. The lava flows are genetically associated with the volcanoes, which are dominantly distributed in the central part of CVSG (Fig. 3). More than 20 lava flows, named $\mathrm{C} 1$ to $\mathrm{C} 16$ in the Chihsingshan, $\mathrm{B} 1$ to $\mathrm{B} 2$ in the Baiyunshan, and $\mathrm{H} 1$ to $\mathrm{H} 2$ in the

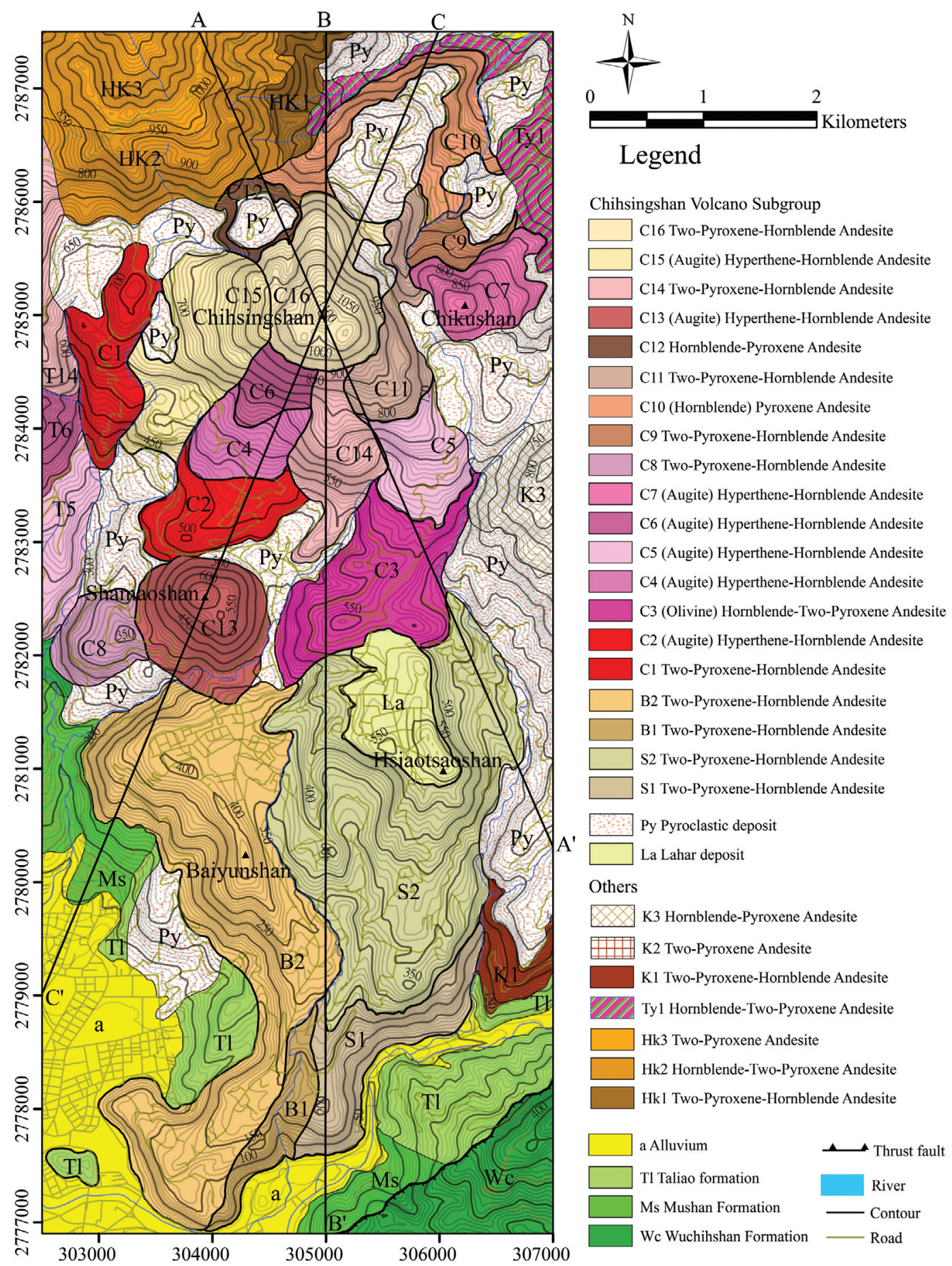

Fig. 3. The detailed geological map of the Chihsingshan Volcano Subgroup. Three cross sections, A - A', B - B', and C - C' are shown in Fig. 8. 
Hsiaotsaoshan, can be identified (Fig. 3). They unconformably overlie a late Teritary sedimentary basement and their ages date from 1.5 Ma to around 0.2 Ma using the Ar-Ar method (Lee 1996). The thickness of the lava ranges from few to tens of meters with a maximum of 300 meters. Variably weathered sequences of pyroclastic flows and tuffs are interlayered with the flows. Some vertical and inclined columnar joints can be seen in the thicker flows, with well developed horizontal to low angle platy joints (Fig. 4).

Most lava flows in the CVSG are basaltic andesites and andesites. Based on the relative contents of mafic phenocrysts, the lava flows can be classified into five types of andesite: two-pyroxene andesite, two-pyroxene hornblende andesite, augite-bearing hypersthene hornblende andesite, hornblende two-pyroxene andesite and hornblende-bearing two-pyroxene andesite (Table 1). Geochemically, CVSG lavas are high-alumina species belonging to the calc-alkaline rock series. $\mathrm{SiO}_{2}$ content increases approximately from 50 $54 \%$ in pyroxene-rich andesites to $53 \sim 56 \%$ in hornblenderich andesites. The concentration of $\mathrm{Na}_{2} \mathrm{O}, \mathrm{K}_{2} \mathrm{O}, \mathrm{Ba}$ and $\mathrm{Sr}$ also increase from pyroxene-rich to hornblende-rich andesites. These chemical characteristics indicate more advanced differentation in later lava flows. Patterns of trace element concentrations normalized to the composition of the primitive mantle show that most of the variations in these lavas are similar. They also show depletions in high field strength elements ( $\mathrm{Ta}$ and $\mathrm{Nb}$ ) and enrichment in large-ion lithophile elements $(\mathrm{Rb}, \mathrm{Ba}, \mathrm{Sr})$ and $\mathrm{Th}$, indicating that they are characteristic of the island arc suite (Fig. 5; Song et al. 2004).

\subsubsection{Pyroclastic Breccias}

Pyroclastic breccias consist predominantly of angular to subangular andesitic lapilli and blocks with matrix of fine crystals, glasses and lithic fragments. They mainly crop out in deeply incised valleys and are interlayered with lava flows in the CVSG, which are predominantly massive clast-supported with subsidiary matrix-supported structures (Fig. 3). A deep well has been drilled in Chinshan Research Center for exploring the sequence of volcanic rocks (Fig. 6). The characteristics of thickness and distribution of the breccias suggest that they probably have two modes of occurrence. One is a massive valley-pond deposit with a very high aspect ratio (thickness/lateral extent), and the other is a veneer deposit with a very low aspect ratio. The former is relatively thick, and occurs as deposits in topographic depressions or paleo-valleys. The latter is relatively thin and can be found in topographic high or distal flat plain of paleovalleys. Meanwhile, blocks of breccias are usually monomict and blocky in nature, and thus distinguishable from the polymict volcaniclastic deposits. Based on the observations, drill wells and outcrops, they may originate from pyroclastic flows which were produced by a lava dome collapse (Cas and Wright 1987).

\subsubsection{Tuffs}

Outcrops of tuffs are very sporadic and occur in restricted areas of the CVSG. Two modes of occurrence can be found. One is interlayered with the pyroclastic breccias, while the other is around the main cones, especially in the Chihsingshan volcano. The former has variable thickness usually with planar- to cross-bedded structures. The characteristic depositional structures indicate that they were probably deposited from pyroclastic surge flows. It should be noted that the latter is massive to faintly bedded and clastsupported, indicative of ash fall deposition.

\subsubsection{Lahar}

Lahars, the secondary volcaniclastic deposits occur sporadically and are only distributed in incised valleys of the CVSG (Fig. 3). Lahars are deposited as rapid watersupported flows of volcaniclastics and occur in and around volcanic aprons (Fisher 1984). They generally show the characteristics of debris-flow deposits (Smith and Lowe 1991). On the other hand, the fluvial volcaniclastic lahars are deposited in the higher flow regime of a river (Davies et al. 1978; Vessell and Davies 1981; Cas and Wright 1987).

The lahar deposits are mainly distributed in the northeastern and southern proximal areas of CVSG, and are nearer the source area than the fluvials. Their thickness varies from several tens of meters at the proximal paleovalleys to less than one meter at distal downstream areas or on a flat land. Polymict andesitic blocks, dominated by two pyroxene and two-pyroxene hornblende andesites, are the major constituents. The deposits show the main features of cold debris flows, including a matrix-supported structure, poor to very poor sorting, non-carbonized woods and lack of stratification and escaping gas structures (Pierson and Scott

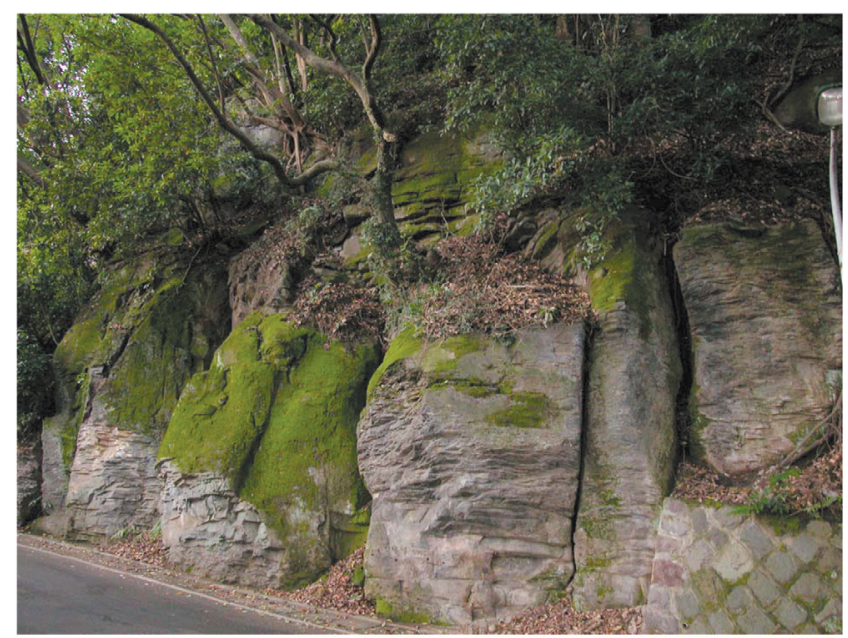

Fig. 4. The thick lava flows have well developed columnar and platy joints in Mt. Shamaoshan. 
Table 1. The petrographic characteristics and Ar-Ar age from lava layers of the Chihsingshan Volcano Subgroup.

\begin{tabular}{|c|c|c|c|c|c|}
\hline \multirow{2}{*}{ Volcano } & \multirow{2}{*}{ Stratigraphy } & \multicolumn{3}{|c|}{ Petrography } & \multirow{2}{*}{ Dating* (Ma) } \\
\hline & & Mineral Assemblages & Groundmass & Rock Types & \\
\hline Chihsingshan & $\mathrm{C} 16$ & Au-Hy-Hb-Plag & Microcrystalline & T-Hb-And & $0.22 \pm 0.04$ \\
\hline Chihsingshan & $\mathrm{C} 15$ & Au-Hy-Hb-Plag & Microcrystalline & (Au)Hy-Hb-And & - \\
\hline Chihsingshan & $\mathrm{C} 14$ & Au-Hy-Hb-Plag & Microcrystalline & T-Hb-And & - \\
\hline Shamaoshan & $\mathrm{C} 13$ & Au-Hy-Hb-Plag & Microcrystalline & (Au)Hy-Hb-And & $0.23 \pm 0.01$ \\
\hline Chihsingshan & $\mathrm{C} 12$ & Hb-Au-Hy-Plag & Microcrystalline & Hb-T-And & $0.24 \pm 0.01$ \\
\hline Chihsingshan & $\mathrm{C} 11$ & Au-Hy-Hb-Plag & Microcrystalline & T-Hb-And & $0.35 \pm 0.01$ \\
\hline Chihsingshan & $\mathrm{C} 10$ & Hb-Au-Hy-Plag & Fine & $(\mathrm{Hb})$-T-And & $0.37 \pm 0.01$ \\
\hline Chihsingshan & C9 & Au-Hy-Hb-Plag & Microcrystalline & T-Hb-And & $0.40 \pm 0.02$ \\
\hline Shamaoshan & $\mathrm{C} 8$ & Au-Hy-Plag & Cryptocrystalline & T-And & $0.41 \pm 0.02$ \\
\hline Chigushan & $\mathrm{C} 7$ & Au-Hy-Hb-Plag & Microcrystalline & (Au)Hy-Hb-And & $0.52 \pm 0.01$ \\
\hline Chihsingshan & C6 & Au-Hy-Hb-Plag & Microcrystalline & (Au)Hy-Hb-And & $0.55 \pm 0.01$ \\
\hline Chihsingshan & $\mathrm{C} 5$ & Au-Hy-Hb-Plag & Glassy & (Au)Hy-Hb-And & $0.72 \pm 0.04$ \\
\hline Chihsingshan & $\mathrm{C} 4$ & Au-Hy-Hb-Plag & Microcrystalline & (Au)Hy-Hb-And & $0.82 \pm 0.01$ \\
\hline Chihsingshan & $\mathrm{C} 3$ & (Ol)-Hb-Au-Hy-Plag & Microcrystalline & (Ol)Hb-T-And & - \\
\hline Chihsingshan & $\mathrm{C} 2$ & Au-Hy-Hb-Plag & Microcrystalline & (Au)Hy-Hb-And & $1.36 \pm 0.07$ \\
\hline Chihsingshan & $\mathrm{C} 1$ & Au-Hy-Hb-Plag & Microcrystalline & T-Hb-And & $1.50 \pm 0.06$ \\
\hline Hsiaotsaoshan & $\mathrm{S} 2$ & Au-Hy-Hb-Plag & Microcrystalline & T-Hb-And & $0.31 \pm 0.01$ \\
\hline Hsiaotsaoshan & $\mathrm{S} 1$ & Au-Hy-Hb-Plag & Microcrystalline & T-Hb-And & $1.32 \pm 0.02$ \\
\hline Baiyunshan & $\mathrm{B} 2$ & Au-Hy-Hb-Plag & Microcrystalline & T-Hb-And & $0.40 \pm 0.01$ \\
\hline Baiyunshan & B1 & Au-Hy-Hb-Plag & Microcrystalline & T-Hb-And & - \\
\hline
\end{tabular}

Note: And: Andesite; Au: Augite; Hb: Hornblende; Hy: Hyperthene; Ol: Olivine; Plag: Plagioclase; T: Two pyroxene; *: Ar-Ar dating (Lee 1996). 


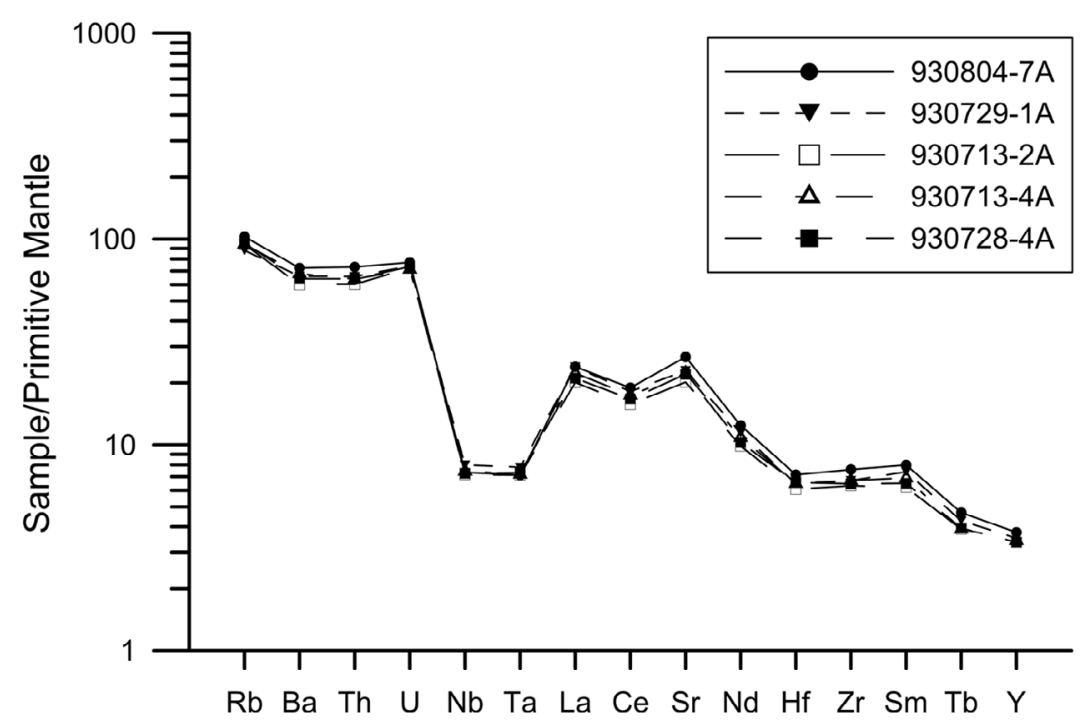

Fig. 5. The primitive mantle-normalized trace-element patterns for andesites from the Chihsingshan Volcano Subgroup (Song et al. 2004).

\section{CGS-93-YMS-01}

$\mathrm{m}$

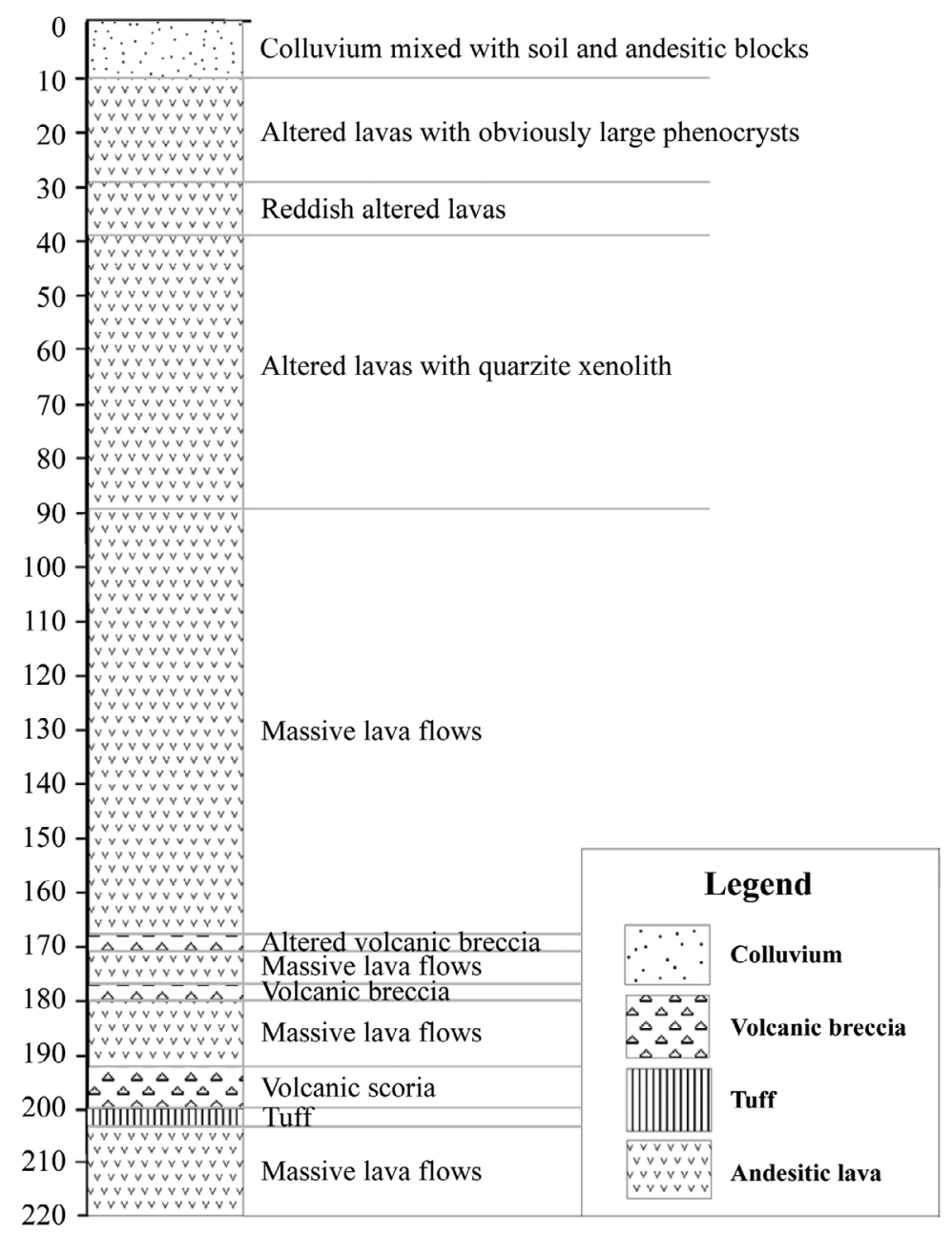

Fig. 6. Lithologic column of drilling core from the Chinshan Research Center in the Chihsingshan Volcano Subgroup. 
1985; Cas and Wright 1987). These deposits can be interpreted as the proximal products of lahar deposits due to collapse of unconsolidated pyroclastic flow deposits through earthquake or heavy rain as those described by Siebert et al. (1987).

\subsection{Volcanic Stratigraphy and Map}

Based on the DTM, topographical map, surface outcrops and occurrences, drilled core sequences and rock ages, the volcanic stratigraphy and geological map can be constructed and drawn. The stratigraphy focuses on the sequences of lava flow, while the map shows the distributions of the volcanic lithofacies. Four lithofacies can be identified and drawn in the map. They are the lava flows, pyroclastic breccias, tuffs and lahars, which are inter-layered with each other. Among them, the lava is dominant with subsidiary breccia and lahar layers, while the tuff is limited in extent. More than 20 units of lava flow are mapped and listed as $\mathrm{C} 1$ to $\mathrm{C} 16$ in the Chihsingshan, $\mathrm{B} 1$ to $\mathrm{B} 2$ in the Baiyunshan, and $\mathrm{H} 1$ to $\mathrm{H} 2$ in the Hsiaotsaoshan, from old to young in sequence (Fig. 3). The sequences of the flows were predominantly determined by age dating and most of them ranged from 1.5 $\mathrm{Ma}(\mathrm{C} 1)$ to around $0.2 \mathrm{Ma}(\mathrm{C} 16)$ (Table 1; Lee 1996). Sequences of the undated C3, C14, C15, and B1 lava flows, were derived from their field relationships of superposition and the distance away from the volcanic center. The northern tip of the C3 is overlain by the C5 (0.72 Ma), and it is distributed farther from the Chihsingshan volcano than the C4 (0.82 Ma). Meanwhile, the C4 has almost the same elevation as $\mathrm{C} 5$ but is older.

Based on aforementioned evidence, the $\mathrm{C} 3$ lava should be older than the $\mathrm{C} 4$ flow, although they do not contact with each other. Lava C14 partly overlies on the flows of C3, $\mathrm{C} 5$, and $\mathrm{C} 11$ (0.35 Ma) in the east, and the flows of $\mathrm{C} 2$, $\mathrm{C} 4$, and C6 (0.40 Ma) in the west (Fig. 7). Meanwhile, the C14 flowed to the northeast of C13 (0.23 Ma, the Shamaoshan). The east boundary of $\mathrm{C} 15$ flow is directly overlain by the youngest $\mathrm{C} 16$ lava $(0.22 \mathrm{Ma})$. Those lines of evidence indicate the lava sequences of the Chihsingshan volcano. The B1 was older than B2 flow, because the B1 had partly covered by $\mathrm{B} 2$ and distribution farther from the summit of the Baiyunshan.

Flow directions of lava measured by magnetic susceptibility anisotropy indicate that all of them almost radiated from the Chihsingshan volcano in the CVSG (Tsai and Lee 1988). Few flows radiated from the Baiyunshan, and Hsiaotsaoshan. Pyroclastic breccias and lahars are predominantly distributed in the proximal area and outskirt of the Chihsingshan volcano, respectively. Most of them interlayer with and/or overlay on the lava flows. A $220 \mathrm{~m}$ deep hole with whole coring was drilled on the east slope of Chihsingshan volcano. It also showed the inter-bedded relationships of thick lavas and thin bedded breccias and lahars with little ash (Fig. 6). Characteristic occurrences of CVSG's volcanic rocks infer that it was represented by effusive or silent rather than violently explosive eruption on the basis of its low volcanic explosivity index.

Three cross sections cut through the N-S, NE-SW, and NW-SE of the CVSG (Fig. 8), indicate that the Chihsingshan is a composite volcano in this subvolcano group. Most of the lava flows predominantly effused from it with subsidiary ones from the Baiyunshan, and Hsiaotsaoshan volcanoes in the CVSG. Moreover, the NE-SW cross section (Fig. 8; C - C') cut through the Shamaoshan dome located in the southwest slope, suggests that Shamaoshan was the parasitic volcano of Chinshihshan.

\subsection{Volcanic Hazards Map}

Volcanic hazards are defined as the probability of a given area being affected by potentially destructive volcanic processes or products within a given period of time (Fournier d'Albe 1979). To mitigate the hazards, therefore, it requires long-term studies for deciphering past eruptive behavior, better understanding present behavior, and by extrapolation, predicting possible future behavior of the volcano. Accordingly, collecting essential data including the distributions, volume, types, petrology, geochemistry and age dating, etc., of historical or prehistorical volcanic deposits and behaviors is important for an adequate hazards assessment for a volcanic area (Tilling 1989). It is assumed that the area likely to be affected by volcanic eruption events in the future would share the same kind of volcanic hazards in the past.

The CVSG is predominantly composed of lava flows with subsidiary pyroclastic flow deposits (breccias), lahars and few tuffs. These characteristics suggest that it was effusive or silent rather than a violently explosive eruption. Accordingly, the major volcanic hazards might be lava and pyroclastic flows and simultaneous or subsequent lahars. Based on two assumptions, that the eruptive center is located in the summit of Chihsingshan and the volume of volcanic deposits exploded by the activity is around 1 $\mathrm{km}^{3}$, which is the same erupted volume as the 18 May 1980 eruption of Mount St. Helens, the volcanic hazard zonation map is shown in Fig. 9. All flows, including lavas, pyroclastic flows and lahars, are characterized by flowing on or along river channels, valleys and/or depressions. Thus, the predominantly volcanic hazards would occur in the center and banks of river or nearby valleys and radiating from the Chihsingshan volcano.

\section{CONCLUSIONS}

The TVG has been defined as an active volcano, located near metropolitan Taipei with over seven million inhabitants and nearby two nuclear power plants. The potential for volcanic activity having devastating impacts and major 
hazards to the area exists. This study focused on observations of the volcanic landforms, stratigraphy and mapping of the CVSG, a subgroup volcano in the TVG. Our results show that the CVSG consist of four volcanic bodies: one composite, the Chihsingshan, two domes, the Shamaoshan and a hidden one, and three lava and pyroclastic cones, Bai- yunshan, Hsiaotsaoshan and Chikushan, respectively, with many small craters distributed linearly along two fault systems. These volcanoes are predominantly composed of lava flows with minor pyroclastics and volcaniclastics, which can be divided into 20 lava units. Based on the past volcanism, the major potential volcanic hazards are likely to

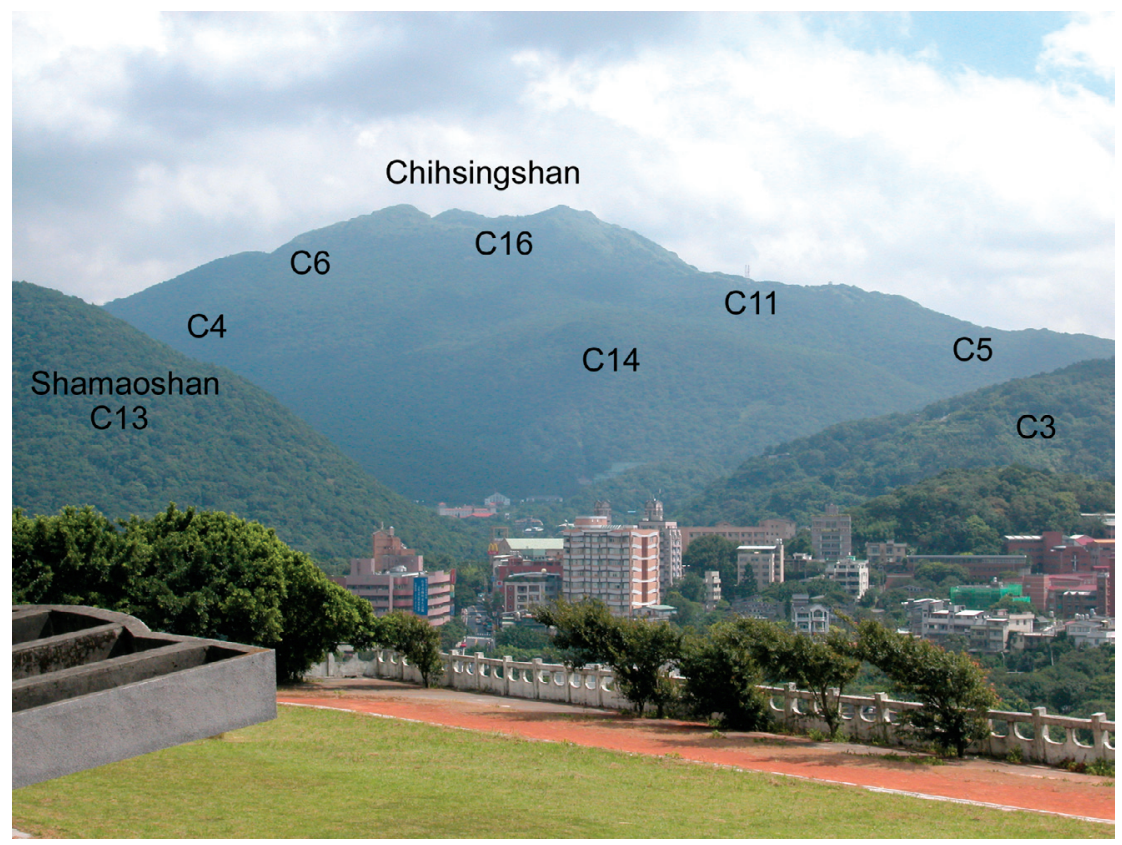

Fig. 7. The spatial distribution of C3 - C6, C11, C13, C14, and C16 lava flows in the Chihsingshan Volcano Subgroup.
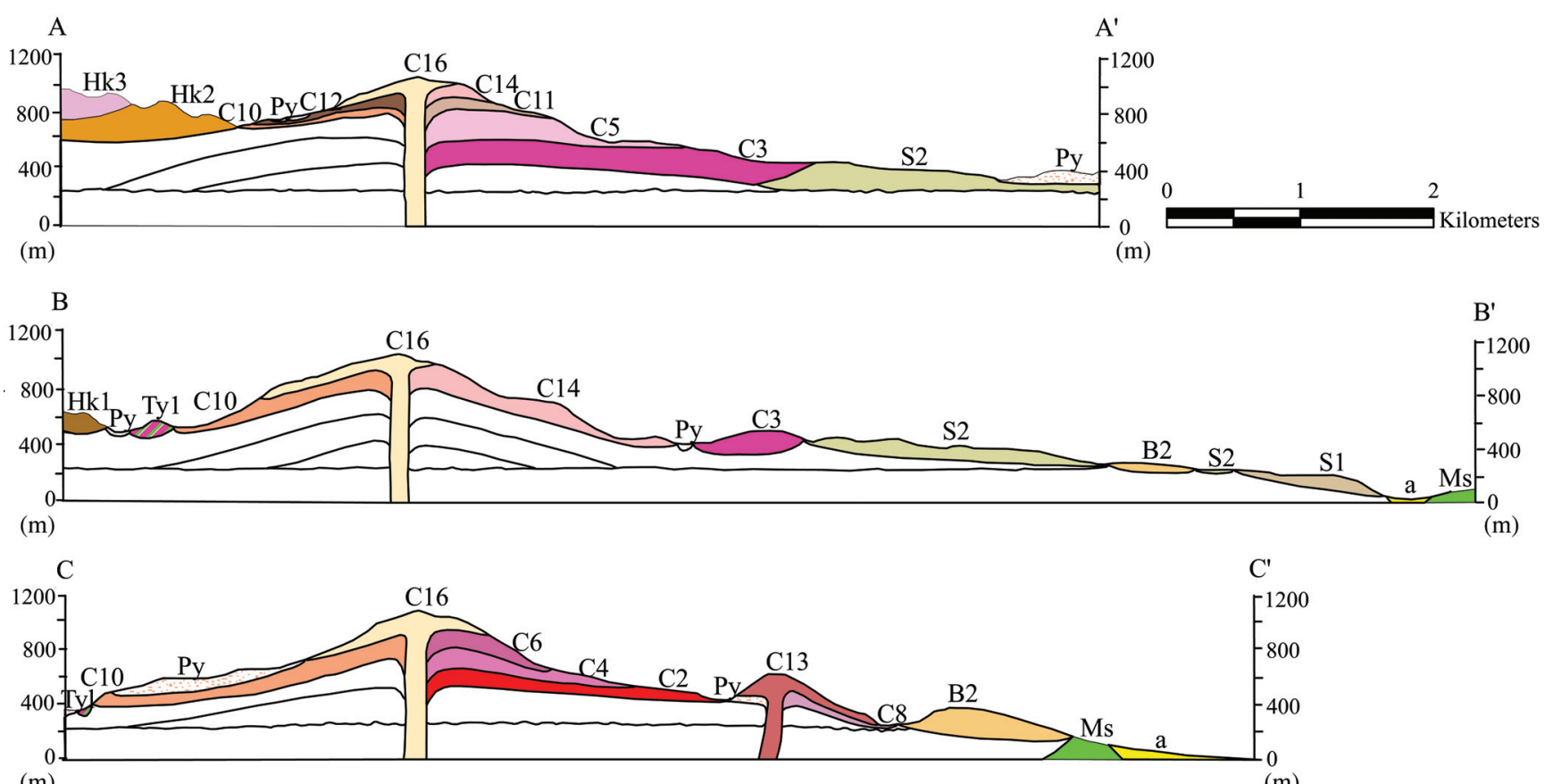

(m)

(m)

Fig. 8. Three cross sections showing the internal structures of the Chihsingshan Volcano Subgroup. Locations are shown in the Fig. 3. Labels of C1 to $\mathrm{C} 16, \mathrm{~B} 1$ to $\mathrm{B} 2$, and $\mathrm{S} 1$ to $\mathrm{S} 2$ representing the layers of lava flow. 


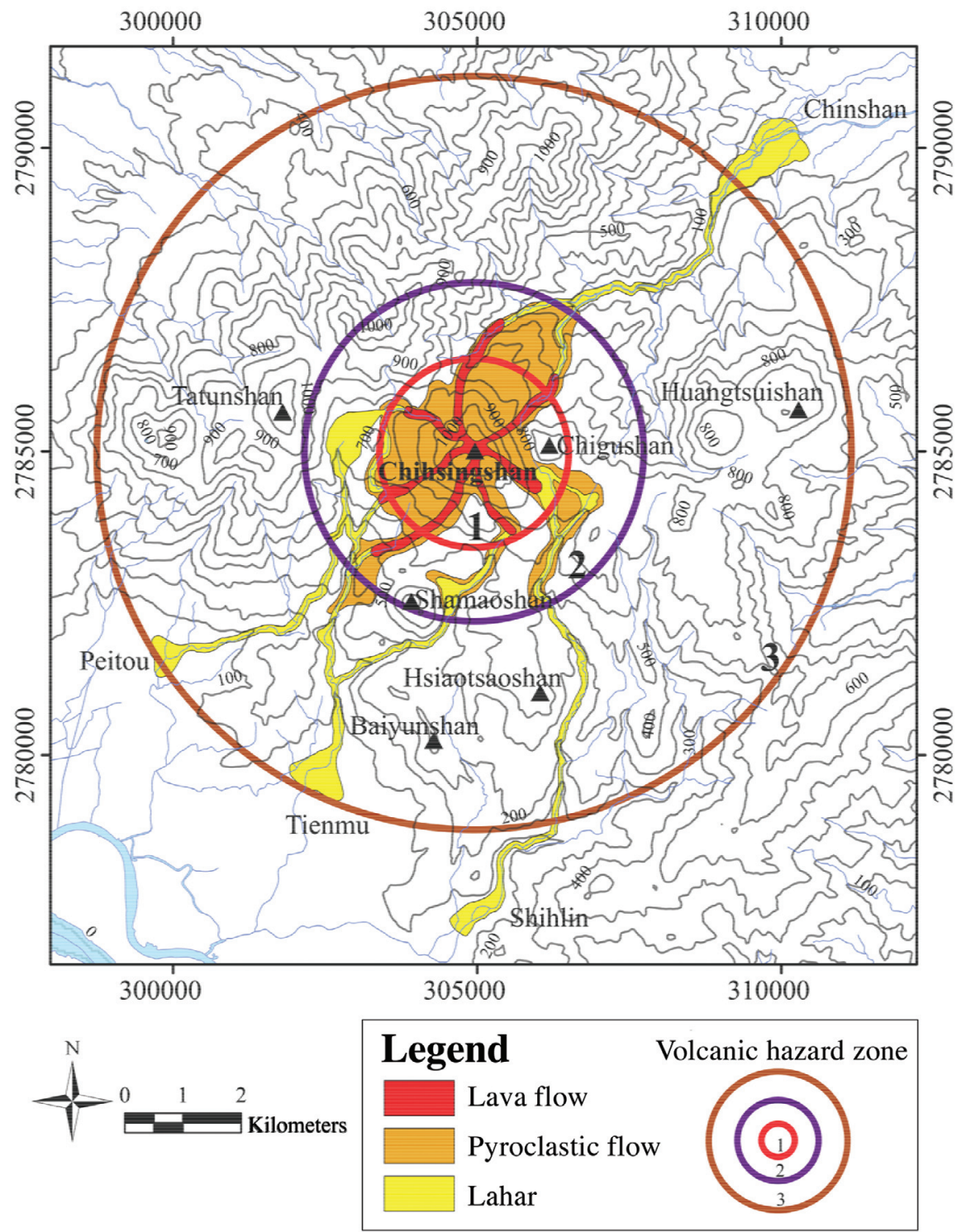

Fig. 9. Volcanic hazard and zonation map derived from the probably eruptive products on the basis of past records. 1: high-hazard zone; 2: mediumhazard zone; 3: low-hazard zone.

be lavas, pyroclastic flows and simultaneous or subsequent lahars, if the volcano erupts in the future. This study has developed a map of volcanic hazards towards the purpose of future hazard mitigation.

Acknowledgements This study was financially supported by the Central Geological Survey, MOEA, Republic of China, under grant No. 5226902000-05-93-01.

\section{REFERENCES}

Cas, R. A. F. and J. V. Wright, 1987: Volcanic Successions, Modern and Ancient: A Geological Approach to Processes, Products, and Successions. Chapman \& Hall, $528 \mathrm{pp}$.
Chen, C., 1978: Petrochemistry and origin of pleistocene volcanic rocks from northern Taiwan. Bull. Volcanol., 41, 513-528, doi: 10.1007/BF02597384. [Link]

Chen, C. H., 1975: Petrological and chemical study of volcanic rocks from Tatun Volcano Group. Proc. Geol. Soc. China, 18, 59-72.

Chen, C. H., 1983: The geochemical evolution of Pleistocence absarokite, shoshonite and high-alumina basalt in northern Taiwan. Mem. Geol. Soc. China, 5, 85-96.

Chen, C. H., 1990: Igneous rocks in Taiwan. Central Geol. Surv., MOEA, ROC, 137 pp. (in Chinese)

Chen, C. H. and Y. J. Wu, 1971: Volcanic geology of the Tatun geothermal area, northern Taiwan. Proc. Geol. Soc. China, 14, 5-20.

Chen, C. H. and C. C. Lin, 2007: The recent eruption of the 
Tatun volcanic group: Inferred from juvenile volcanic ash in the Taipei basin. Abstract in the Annual Meeting of Geological Society, Taipei.

Chen, W. S., C. C. Yang, H. C. Yang, and J. K. Liu, 2003: Volcanic landform and sequences of the Tatun Volcanoes. Bull. Cent. Geol. Surv., 16, 99-123. (in Chinese)

Davis, D. K., R. C. Vessell, R. C. Miles, M. G. Foley, and S. D. Bonis, 1978: Fluvial transport and downstream sediment modifications in an active volcanic region. In: Miall, A. (Ed.), Fluvial Sedimentology. Can. Soc. Pet. Geol. Mem., 5, 61-84.

Fisher, R. V., 1984: Submarine volcaniclastic rocks. In: Kokelaar B. P. and M. F. Howell (Eds.), Marginal Basin Geology. Geol. Soc. Spec. Pub., 16, 5-28.

Fournier d'Albe, E. M., 1979: Objectives of volcanic monitoring and prediction. J. Geol. Soc. London, 136, 321326, doi: 10.1144/gsjgs.136.3.0321. [Link]

Ho, C. S., 1986: A synthesis of the geologic evolution of Taiwan. Tectonophysics, 125, 1-16, doi: 10.1016/00401951(86)90004-1. [Link]

Huang, C. S., 2005: Explanatory text of the geologic map of Taiwan: Taipei sheet (Scale 1:50000). 3rd, Central Geological Survey MOEA, Taipei, 57 pp. (in Chinese)

Juang, W. S., 1993: Diversity and origin of Quaternary basaltic magma series in northern Taiwan. Bull. Natl. Museum Nat. Sci., 4, 125-166.

Juang, W. S. and J. C. Chen, 1989: Geochronology and geochemistry of volcanic rocks in northern Taiwan. Bull. Geol. Surv., 5, 31-66. (in Chinese)

Lee, S. F., 1996: Volcanic sequence study of the Tatun Volcano Group: The Chihsinshan Subgroup. Master Thesis, Institute of Geology, National Taiwan University, Taipei, Taiwan, ROC, 136 pp. (in Chinese)

Lin, C. H., K. I. Konstantinou, H. C. Pu, C. C. Hsu, Y. M. Lin, S. H. You, and Y. P. Huang, 2005: Preliminary results from seismic monitoring at the Tatun volcanic area of northern Taiwan. Terr. Atmos. Ocean. Sci., 16, 563-577.

Miller, C. L. and R. A. Leflamme, 1958: The digital terrain model - Theory and application. Photo. Eng., 24, 433-442.

Ollier, C., 1988: Volcanoes. Basil Blackwell, Oxford, 228 pp.

Pierson, T. C. and K. M. Scott, 1985: Downstream dilution of a lahar: Transition from debris flow to hyperconcentrated streamflow. Water Resour. Res., 21, 1511-1524, doi: 10.1029/WR021i010p01511. [Link]

Siebert, L., 1984: Large volcanic debris avalanches: Characteristics of source areas, deposits, and associated eruptions. J. Volcanol. Geotherm. Res., 22, 163-197, doi: 10.1016/0377-0273(84)90002-7. [Link]

Siebert, L., H. Glicken, and T. Ui, 1987: Volcanic hazards from Bezymianny- and Bandai-type eruptions. Bull. Volcanol., 49, 435-459, doi: 10.1007/BF01046635. [Link]
Smith, R. L. and D. R. Lowe, 1991: Lahars: volcano-hydrologic events and deposition in the debris-flow-hyperconcentrated flow continuum. In: Fisher, R. V. and G. A. Smith, (Eds.), Sedimentation in Volcanic Settings. SEPM Spec. Pub., 45, 59-70.

Song, S. R., S. Tsao, and H. J. Lo, 2000a: Characteristics of the Tatun Volcanic eruptions, north Taiwan: Implications for a cauldron formation and volcanic evolution. J. Geol. Soc. China, 43, 361-378.

Song, S. R., T. Y. Yang, Y. H. Yeh, S. Tsao, and H. J. Lo, 2000b: The Tatun Volcano Group is active or extinct? J. Geol. Soc. China, 43, 521-534.

Song, S. R., T. F. Yang, and W. Lo, 2004: Geological and geochemical investigation and monitoring for volcanic hazards in metropolitan Taipei (1/4). Report No. 93-03 of Central Geological Survey MOEA, Taipei, Taiwan, ROC. (in Chinese)

Suppe, J., 1984: Kinematics of arc-continent collision, flipping of subduction, and back-arc spreading near Taiwan. Mem. Geol. Soc. China, 6, 21-34.

Szakacs, A., 1994: Redefining active volcanoes: A discussion. Bull. Volcanol., 56, 321-325, doi: 10.1007/ BF00326458. [Link]

Teng, L. S., 1996: Extensional collapse of the northern Taiwan mountain belt. Geology, 24, 949-952, doi: 10.11 30/0091-7613(1996)024<0949:ECOTNT>2.3.CO;2. [Link]

Teng, L. S., C. H. Chen, W. S. Wang, T. K. Liu, W. S. Juang, and J. C. Chen, 1992: Plate kinematic model for late Cenozoic arc magmatism in northern Taiwan. $J$. Geol. Soc. China, 35, 1-18.

Tilling, R. I., 1989: Volcanic hazards. Short Course in Geology, American Geophysical Union, Washington, DC.

Tsai, P. F. and T. Q. Lee, 1988: Magnetic suspectivity anisotropy of the Tatun Volcano Group. J. Geol. Soc. China, 31, 73-86.

Tsai, Y. B., Z. S. Liaw, T. Q. Lee, M. T. Lin, and Z. H. Yeh, 1981: Seismological evidence of an active plate boundary in the Taiwan area. Mem. Geol. Soc. China, 4, 143-154.

Tsao, S., 1994: K-Ar age determination of volcanic rocks from the Tatun Volcano Group. Bull. Cent. Geol. Surv., 9, 137-154. (in Chinese)

Vessell, R. K. and D. K. Davis, 1981: Non-marine sedimentation in an active fore-arc basin. In: Ethridge, F. G. and R. M. Flores, (Eds.), Recent and Ancient Non-Marine Depositional Environments: Models for Exploration. SEPM Spec. Pub., 31, 31-45.

Wang, K. L., S. L. Chung, C. H. Chen, R. Shinjo, T. F. Yang, and C. H. Chen, 1999: Post-collisional magmatism around northern Taiwan and its relation with opening of the Okinawa Trough. Tectonophysics, 308, 363-376, doi: 10.1016/S0040-1951(99)00111-0. [Link]

Wang, W. H. and C. H. Chen, 1990: The volcanology and 
fission track age dating of pyroclastic deposits in Tatun Volcano Group. Acta Geol. Taiwan., 28, 1-30.

Wu, F. T., 1978: Recent tectonics of Taiwan. J. Phys. Earth, 26, s265-s300.

Yen, T. P., 1978: Geologic relations between northern Tai- wan and southern Ryukyu islands. Acta Oceanogr. Taiwan., 8, 1-21.

Yen, T. P., Y. H. Tzou, and W. H. Lin, 1984: Subsurface geology of the Tatun Volcano Group. Petrol. Geol. Taiwan, 20, 143-154. 